\title{
Human heat shock cognate protein (HSC70/HSPA8) interacts with negatively charged phospholipids by a different mechanism than other HSP70s and brings HSP90 into membranes
}

\author{
Paulo R. Dores-Silva ${ }^{1,2}$ - David M. Cauvi ${ }^{1}$ - Amanda L. S. Coto ${ }^{2} \cdot$ Noeli S. M. Silva ${ }^{2}$ - Júlio C. Borges ${ }^{2}$. \\ Antonio De Maio ${ }^{1,3}$ (i)
}

Received: 16 March 2021 / Revised: 28 April 2021 / Accepted: 1 May 2021 / Published online: 18 May 2021

(C) Cell Stress Society International 2021

\begin{abstract}
Heat shock proteins (HSP) are critical elements for the preservation of cellular homeostasis by participating in an array of biological processes. In addition, HSP play an important role in cellular protection from various environmental stresses. HSP are part of a large family of different molecular mass polypeptides, displaying various expression patterns, subcellular localizations, and diversity functions. An unexpected observation was the detection of HSP on the cell surface. Subsequent studies have demonstrated that HSP have the ability to interact and penetrate lipid bilayers by a process initiated by the recognition of phospholipid heads, followed by conformational changes, membrane insertion, and oligomerization. In the present study, we described the interaction of HSPA8 (HSC70), the constitutive cytosolic member of the HSP70 family, with lipid membranes. HSPA8 showed high selectivity for negatively charged phospholipids, such as phosphatidylserine and cardiolipin, and low affinity for phosphatidylcholine. Membrane insertion was mediated by a spontaneous process driven by increases in entropy and diminished by the presence of ADP or ATP. Finally, HSPA8 was capable of driving into the lipid bilayer HSP90 that does not display any lipid biding capacity by itself. This observation suggests that HSPA8 may act as a membrane chaperone.
\end{abstract}

Keywords Hsp70 $\cdot$ HSPA8 $\cdot$ HSPA1A $\cdot$ HSP90AA1 $\cdot$ Liposomes $\cdot$ Phospholipids $\cdot$ Membranes $\cdot$ Chaperones

\section{Introduction}

Proteostasis is an essential process for the assurance of cell survival by controlling the dynamic balance between protein biogenesis, folding, translocation into subcellular compartments, and degradation (Hartl et al. 2011; Klaips et al. 2018). In addition, cells are frequently exposed to a variety of environmental stresses, including hyperthermia, oxidative damage, glucose-depletion, inflammation, infection, among

Antonio De Maio

ademaio@health.ucsd.edu

1 Department of Surgery, School of Medicine, Division of Trauma, Critical Care, Burns and Acute Care Surgery, University of California, San Diego, La Jolla, CA 92093, USA

2 São Carlos Institute of Chemistry, University of São Paulo, São Paulo, Brazil

3 Department of Neurosciences, School of Medicine, University of California San Diego, La Jolla, CA 92093, USA others. Under these stress conditions, the appearance of misfolded proteins compromises cellular processes affecting cell viability (De Maio 1999). Moreover, several pathologies are associated with the occurrence of misfolded and aggregated proteins, such as Parkinson's, Alzheimer's, and Huntington's diseases (Mogk et al. 2018). In order to control this plethora of stresses and maintain cellular homeostasis, the expression of heat shock proteins (HSP) is a universal response (Lindquist and Craig 1988; De Maio 1999 ). HSP are composed of a variety of different molecular mass polypeptides, with various expression patterns, subcellular localization, and diversity functions that are necessary to preserve proteostasis (De Maio 1999; Hartl et al. 2011).

The variety of cellular functions executed by HSP have overpassed the initial recognized activity of protein folding. Indeed, HSP are involved in assembly and disassembly of protein complexes, stabilization of nuclear receptors, association with intermediary pathway components, transport of proteins across subcellular organelle membranes, and more recently, their export outside cells where they are acting as extracellular signaling mediators (De Maio 2011), biomarkers 
(Pockley et al. 2014), and protective agents (Rivera et al. 2018). An unexpected and remarkable observation was the detection of HSP on the cell surface, particularly on cancer cells (Multhoff and Hightower 2011). Surface HSP70 (HSPA1) has been proposed to play a role in the survival of transformed cells and an interface with the immune system (Balogi et al. 2019; Multhoff et al. 2020). Cell surface HSPA5 (GRP78, BIP) has been reported as a receptor for a variety of viruses (Honda et al. 2009; Kottom et al. 2018; Chu et al. 2018; Ibrahim et al. 2020). Recently, GRP78 was found as auxiliary factor for SARS-CoV-2 entry and infection by interacting with the putative viral receptor angiotensinconverting enzyme 2 (Carlos et al. 2021). In addition, the interaction of HSP70s with membranes has been associated with the endocytic process (Vega et al. 2010), phagocytosis (Vega and De Maio 2005), and the transport of proteins into endosomes as part of the microautophagy (Sahu et al. 2011). HSPA8 has also been associated with morphogenesis (Mills et al. 2010). Moreover, HSP70 interacts with and shelters the lysosome membrane from the content leakage (Nylandsted et al. 2004). In general, the association of HSP with membranes has been envisioned as a stabilizer of biological membranes and a sensor for thermal stress (Balogi et al. 2019; Balogh et al. 2013). The interaction of HSP with membranes is also recognized as part of the mechanism for extracellular export, perhaps involving exosomes (De Maio 2011; Gastpar et al. 2005; Vega et al. 2008; Gobbo et al. 2016; Chanteloup et al. 2020).

Previous studies have shown that the association and insertion of HSP70 into membranes is a complex process that is initiated by the interaction with negatively charged phospholipids that is likely followed by a conformational change permitting the penetration into the core of the lipid bilayer (De Maio 2011; Armijo et al. 2014). The insertion of HSP70 into membranes is a spontaneous process due to increases in entropy, likely due to the displacement of water molecules from the surface of the protein (Dores-Silva et al. 2020a, 2020b). Human $71 \mathrm{kDa}$ heat shock cognate protein (HSC70, also known as HSPA8, Hsp70-8, Hsc71, Hsp71, or Hsp73), which is constitutively present in cells participating in the folding of newly synthesized polypeptides as well as other specific functions, including endocytosis, was found to get inserted into lipid bilayers opening an ion conductance pathway (Arispe and De Maio 2000; Macazo and White 2014). The channel activity was very stable with a conductance regulated by nucleotides in which ATP opens, and ADP closes the channels suggesting that conformational changes may regulate the ion pathway (Arispe and De Maio 2000). The interaction of HSPA 8 with membranes showed specificity for phosphatidylserine (PS) similar to other HSP70 (Arispe et al. 2002, 2004). Binding to endosomal membranes containing PS on the cytosolic side was reported to mediate the process of microautophagy (Sahu et al. 2011; Morozova et al.
2016). Moreover, HSPA 8 was detected on the surface of fetal rat liver ductal cells, hepatic progenitor cells, mature cholangiocytes, and hepatocellular carcinoma (Mills et al. 2010).

In the present study, we expand the investigation on the interaction of HSPA8 with lipid membranes, using liposomes made with different phospholipid moieties. Like other human HSP70s, HSPA8 showed a high propensity for the insertion into liposomes made with negatively charged phospholipids, such as palmitoyl-oleoyl phosphoserine (POPS) and cardiolipin $\left(1^{\prime}, 3^{\prime}\right.$-bis[1,2-dimyristoyl-sn-glycero-3-phospho]glycerol) (CL). Thermodynamic analysis indicated that membrane insertion is a spontaneous process driven by increases in entropy. Moreover, membrane insertion was blocked by the addition of nucleotides.

\section{Materials and methods}

\section{Sequence and alignment of HSP70s and the human HSP90 AA1 and AB1 proteins}

The amino acid sequence of the HSPA8 (UniProtKB-P11142) was aligned with the sequences of other human Hsp70 isoforms: HSPA1A (UniProtKB-P0DMV8), HSPA5 (UniProtKB-P11021) without the leading signal peptide for ER translocation, HSPA9 (UniProtKB-P38646) without the leading signal peptide for mitochondrial translocation, and Hsp70 from Escherichia coli (DnaK: UniProtKB-P0A6Y8). For the global alignment, the Clustal Omega online tool (https://www.ebi.ac.uk/Tools/msa/clustalo/) was used. The Sednterp program (http://www.jphilo.mailway.com) was used for extracting the theoretical isoelectric point as well as protein charge as a function of $\mathrm{pH}$.

\section{HSPA8 modelling}

The Swiss-Model program (SWISS-MODEL (expasy.org) was used to generate the homology models for HSPA8 (1646 a.a.) in the closed and open states. For the closed state, the PDBs templates 3C7N.1.B (HSPA8 covered 1-554 a.a. with $100 \%$ of identity) and 2KHO.1.A (HSPA8 covered 1612 a.a. with $50 \%$ of identity) were employed. For open conformation, the templates used were 6ASY.1.A (HSPA8 covered 1-606 a.a. with $66 \%$ of identity).

\section{Protein expression and purification}

The recombinant proteins were expressed as previously described (Borges and Ramos 2006; Dores-Silva et al. 2020a, 2020b; Minari et al. 2019). The recombinant proteins were isolated by a single chromatographic step on a $\mathrm{Ni}^{2+}$. immobilized affinity column, step-washed with $20 \mathrm{mM}$ 
phosphate buffer ( $\mathrm{pH} 7.5$ ) containing $100 \mathrm{mM} \mathrm{NaCl}$. The protein was eluted in the same buffer with the addition of imidazole $(500 \mathrm{mM})$ and subjected to exhaustive dialysis against $50 \mathrm{mM}$ Tris-HCl buffer ( $\mathrm{pH} 7.5)$. The production and purification of the Hsps were evaluated by lithium dodecyl sulfate polyacrylamide gel electrophoresis (LDS-PAGE). The protein concentrations were determined spectrophotometrically using the calculated extinction coefficient in native conditions (PACE approach), estimated by the Sednterp program.

\section{HSPA8 and HSPA1A structural and functional characterization}

The secondary structure of HSPA 8 and HSPA1A was assessed by circular dichroism before and after incorporation into POPS liposomes ( $1 \mathrm{mM})$, using a J-815 spectropolarimeter (Jasco Inc.) coupled to the thermoelectric control system PFD 425S: the HSPA8 or HSPA1A in $50 \mathrm{mM}$ Tris-HCl buffer ( $\mathrm{pH} 7.5$ ) at concentrations at $\sim 2 \mu \mathrm{M}$ using a 1-mm path length cuvette at $25^{\circ} \mathrm{C}$. All data were normalized to the mean residue ellipticity $([\Theta])$, and spectral deconvolution was performed using the Dichroweb program (http://dichroweb.cryst.bbk.ac. $\mathrm{uk} / \mathrm{html} / \mathrm{home} . \mathrm{shtml}$ ) (Whitmore and Wallace 2008).

The tertiary structures of recombinant HSPA 8 and HSPA1A before and after incorporation into POPS liposomes $(1 \mathrm{mM})$ were evaluated by intrinsic emission fluorescence. The measurements were performed in an F-4500 Fluorescence Spectrophotometer (Hitachi) using a $1 \times$ $0.2 \mathrm{~cm}$ path length cuvette with HSPA8 or HSPA1A at $2 \mu \mathrm{M}$ in $50 \mathrm{mM}$ Tris- $\mathrm{HCl}$ buffer $(\mathrm{pH} 7.5)$ at $20{ }^{\circ} \mathrm{C}$. The emission fluorescence was measured from 300 up to $420 \mathrm{~nm}$ after excitation at $295 \mathrm{~nm}$ with a 4-nm bandpass. The data were analyzed by their maximum emission wavelength $\left(\lambda_{\max }\right)$ and spectral center of mass $(<\lambda>)$, as previously described (Dores-Silva et al. 2012).

The functionalities of purified recombinant HSPA8 and HSPA1A were evaluated by measuring the proteins ATPase activity as described by Kiraly et al. (2020) by using the Pi ColorLock ${ }^{\mathrm{TM}}$ kit (Innova Biosciences). HSPA8 (or HSPA1A) at $\sim 2 \mu \mathrm{M}$ was prepared in $50 \mathrm{mM}$ Tris- $\mathrm{HCl}$ buffer $(\mathrm{pH} 7.5)$ and incubated with ATP $\left(2 \mathrm{mmol} \mathrm{L}^{-1}\right)$ in the presence of $\mathrm{MgCl}_{2}(2 \mathrm{mM})$ for $30 \mathrm{~min}$ at $37^{\circ} \mathrm{C}$. The negative control was prepared without recombinant proteins. Finally, the Hsp70 ATPase activities were measured spectrophotometrically based on the change in absorbance of the malachite green dye in the presence of phosphomolybdate complexes.

\section{Liposome preparation and incorporation of proteins}

Liposomes were prepared using the extrusion method (Lopez et al. 2016; Dores-Silva et al. 2020a, 2020b).
Briefly, palmitoyl-oleoyl phosphocholine (POPC), palmitoyl-oleoyl phosphoserine (POPS), palmitoyl-oleoyl phosphoethanolamine (POPE), and cardiolipin, $1^{\prime}, 3^{\prime}$ bis[1,2-dimyristoyl-sn-glycero-3-phospho]-glycerol (CL) (Avanti Polar Lipids) were dissolved in $\mathrm{CHCl}_{3}(10 \mathrm{mg} /$ $\mathrm{mL}$ ) and dried under a nitrogen gas stream. The dried lipid $(400 \mu \mathrm{g})$ was resuspended in $50 \mathrm{mM}$ Tris- $\mathrm{HCl}$ buffer $(\mathrm{pH}$ 7.5 ) or $50 \mathrm{mM}$ Tris- $\mathrm{HCl}$ buffer (pH 9.0) or $50 \mathrm{mM}$ acetate buffer ( $\mathrm{pH}$ 5.0) vortexed 6 times for $30 \mathrm{~s}$ with intervals of 5 min. The suspension was extruded using a $100-\mathrm{nm}$ membrane filter by 15 passages. The size of the liposomes (100 nm) was confirmed by Nano Tracking Analysis (NTA) using the NanoSight NS300 instrument. Liposomes (400 $\mu \mathrm{g})$ were incubated with the respective proteins in acetate $50 \mathrm{mM}$ buffer (pH 5) or Tris-HCl buffer ( $\mathrm{pH} 7.5$ ), or Tris$\mathrm{HCl}$ buffer (pH 9.0) for $30 \mathrm{~min}$ at $25^{\circ} \mathrm{C}$ in the presence or absence of $1 \mathrm{mM}$ of ATP or ADP with continuous agitation. The assay was performed at $25{ }^{\circ} \mathrm{C}$ since higher temperatures may compromise the integrity of the lipid bilayer. The mixture was centrifuged at $100,000 \times g$ for $1 \mathrm{~h}$ at $4{ }^{\circ} \mathrm{C}$. The pellet was resuspended $(300 \mu \mathrm{L})$ in $100 \mathrm{mM} \mathrm{Na}_{2} \mathrm{CO}_{3}$ buffer (pH 11.5) and centrifuged at $100,000 \times g$ for $1 \mathrm{~h}$ at $4{ }^{\circ} \mathrm{C}$. The pellet was solubilized in sample buffer in the presence or absence of $10 \mathrm{mM}$ of $\beta$-mercaptoethanol $(\beta-\mathrm{M})$, and the proteins were resolved by LDS-PAGE and visualized by staining with Coomassie Brilliant Blue R-250 (Thermofisher Scientific, Waltham, MA). The GelQuant software (http://biochemlabsolutions.com/GelQuantNET. html) was used to estimate the intensity of bands in the gel and the percentage of HSPA 8 or HSPA1A incorporated into the liposomes.

\section{Isothermal titration calorimetry}

The interaction of HSPA8 with POPS and CL liposomes was assessed by isothermal titration calorimetry (ITC) using an iTC200 microcalorimeter (GE Healthcare Life Sciences) as previously described by Dores-Silva et al. 2020a and DoresSilva et al. 2020b. Briefly, seventeen aliquots of $2 \mu \mathrm{L}$ of liposomes (POPS or CL) at $3 \mathrm{mM}$ were titrated into 203.8 $\mu \mathrm{L}$ of $10 \mu \mathrm{M}$ of HSPA 8 at $25^{\circ} \mathrm{C}$. The curves were analyzed to yield the association constant $\left(\mathrm{K}_{\mathrm{A}}\right)$ and apparent enthalpy change $\left(\Delta \mathrm{H}_{\mathrm{app}}\right)$. The dissociation constant $\left(\mathrm{K}_{\mathrm{D}}\right)$ was obtained as the inverse of $\mathrm{K}_{\mathrm{A}}$. The apparent Gibbs energy change $\left(\Delta \mathrm{G}_{\mathrm{app}}\right)$ was calculated using the relation $[\Delta \mathrm{G}]_{\mathrm{app}}=$ $\mathrm{RT} \ln \mathrm{K}_{\mathrm{A}}$ and the apparent entropy change $[\Delta \mathrm{S}]_{\mathrm{app}}$ was determined by the equation: $[\Delta \mathrm{G}]_{\mathrm{app}}=[\Delta \mathrm{H}]_{\mathrm{app}}-\mathrm{T}[\Delta \mathrm{S}]_{\mathrm{app}}$.

\section{Recombinant HSPA8 resistance to protease digestion}

Recombinant HSPA8 (5 $\mu \mathrm{g})$ incorporated into POPS liposomes $(400 \mu \mathrm{g})$ was incubated with proteinase $\mathrm{K}\left(5 \mu \mathrm{g} \mathrm{m}{ }^{-1}\right)$ for $1 \mathrm{~h}$ at $25{ }^{\circ} \mathrm{C}$ in $50 \mathrm{mM}$ Tris-HCl buffer (pH 7.5). Afterward, the 
HSPA8 liposomes were centrifuged at $100,000 \times g$ for $1 \mathrm{~h}$ at $4{ }^{\circ} \mathrm{C}$. Pellets were resuspended in LDS sample buffer in the presence of $10 \mathrm{mM}$ of $\beta-\mathrm{M}$, resolved by LDS-PAGE, and visualized using Coomassie Brilliant Blue R-250 staining.

\section{Results}

\section{The recombinant HSPA8 and HSPA1A were produced with high purity}

Recombinant HSPA8 and HSPA1A containing a His-tag connected to the $\mathrm{N}$-terminal end of the protein were expressed in bacteria and purified by $\mathrm{Ni}^{2+}$-affinity chromatography in one step. The recombinant proteins showed a $92 \%$ purity as indicated by LDS-PAGE (Fig. 1A and B for HSPA8 and HSPA1A, respectively). Circular dichroism and intrinsic tryptophan fluorescence analysis indicated that the recombinant proteins displayed the expected secondary and tertiary signatures (Fig. 1C). In order to assess whether the recombinant HSPA8 and HSPA1A were active, we evaluated their ability
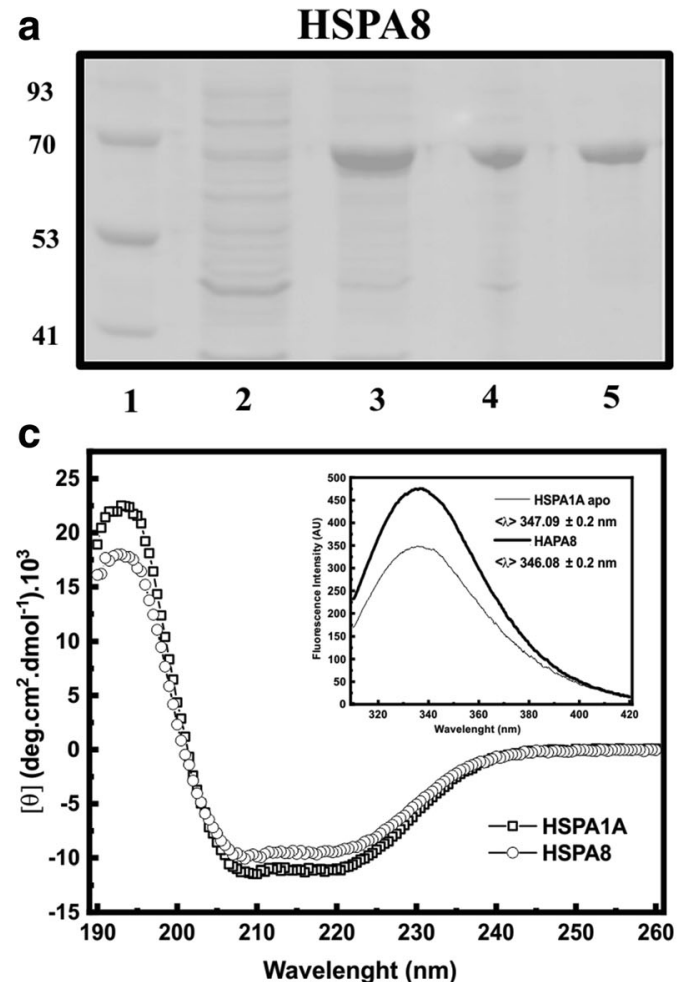

Fig. 1 Purification and characterization of recombinant HSPA8. HSPA8 (A) and HSPA1 (B) were purified using $\mathrm{Ni}^{2+}$-affinity chromatography in one step as described under Methods. All steps for the production and isolation process were visualized by LDS-PAGE and Coomassie Brilliant Blue R-250 staining: lane 1, molecular weight markers: lane 2, bacterial lysate without induction; lane 3, bacterial lysate after IPTG induction; lane 4 , supernatant of the bacteria lysate; lane 5 , purified recombinant to hydrolyze ATP. The ATP activity of HSPA8 was elevated with respect to HSPA1A (Fig. 1D).

\section{HSPA8 interacts preferentially with liposomes made with POPS or CL}

Previous studies showed that various members of the HSP70 family interacted with high selectively for liposomes made with negatively charged phospholipids (Arispe et al. 2004; Schilling et al. 2009; Armijo et al. 2014; Dores-Silva et al. 2020a, 2020b). We investigated whether HSPA8 displays a similar interaction with phospholipid bilayers. HSPA8 was incubated with unilamellar liposomes made with POPC, POPS, POPE, and CL phospholipids that correspond to the major component of cellular membranes. The incorporation of HSPA8 into liposomes was determined by LDS-PAGE and staining with Coomassie Brilliant Blue R-250 as described under Methods. For each type of liposome, the protein incorporation into the liposomes (positive signals) was compared with the total amount of protein used in the assay (negative signals).

b

HSPA1A

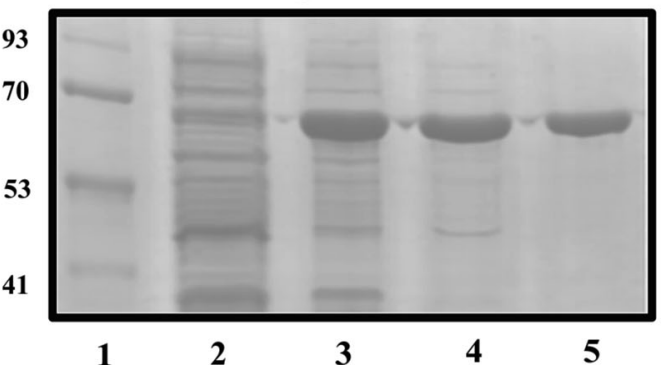

d

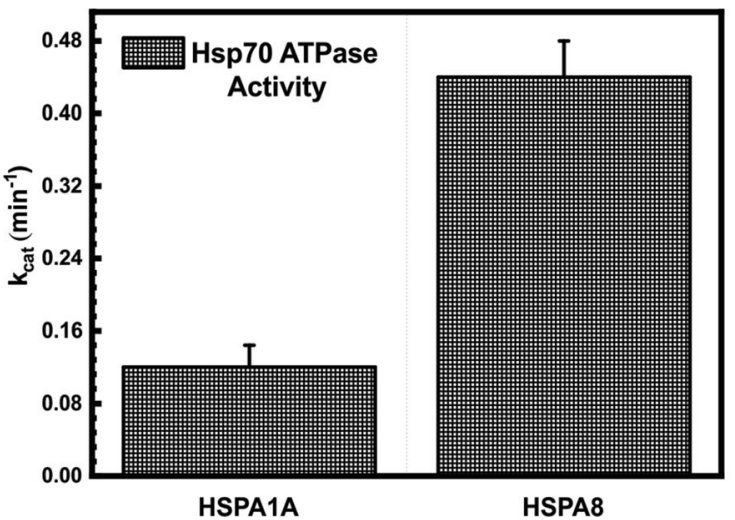

protein. Protein secondary and tertiary structures were assessed by circular dichroism and intrinsic tryptophan fluorescence as described under Methods (C). ATPase activity of both HSPA8 and HSPA1 was measured as described under Methods (D); notice that the activity is elevated for HSPA8 in comparison with HSPA1A. These results all together showed that HSPA 8 and HSPA1A used in this study were produced with high purity, presenting the expected structure and function 
HSPA8 presented preferential affinity for negatively charged phospholipids (POPS and CL). Moreover, HSPA8 showed a lower affinity for POPC liposomes, whereas there was no interaction with POPE liposomes (Fig. 2A). These observations were in contrast with the association of HSPA1A with membranes that did not present any affinity for POPC liposomes (Fig. 2B). A comparison of the percentage of association with various phospholipids between HSPA8 and HSPA1A showed a remarkably good interaction of both proteins with POPS and CL, but a different association with POPC (Fig. 2C). The results also pointed out that the interaction with

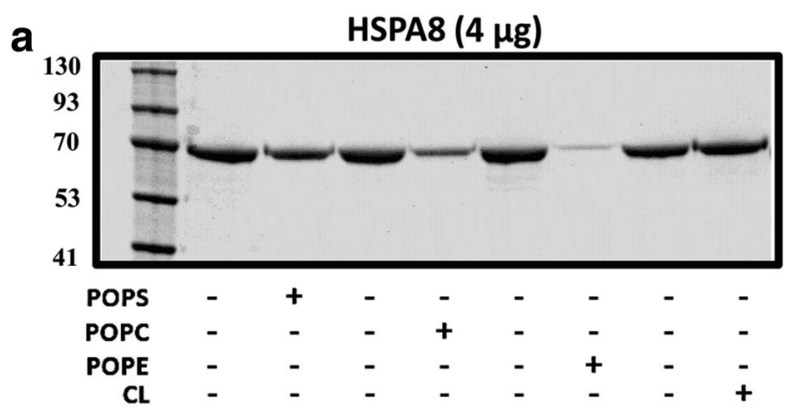

b

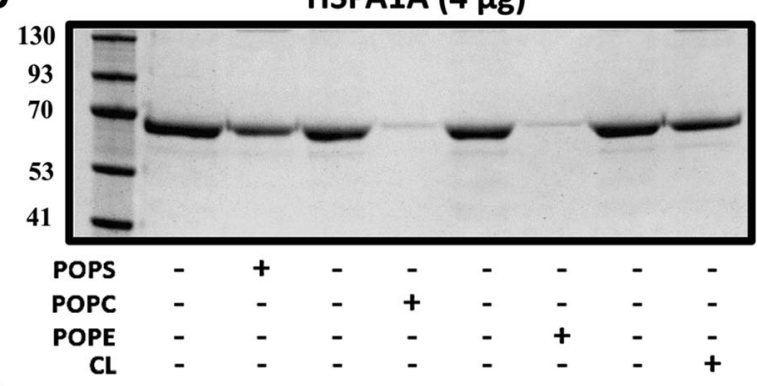

C

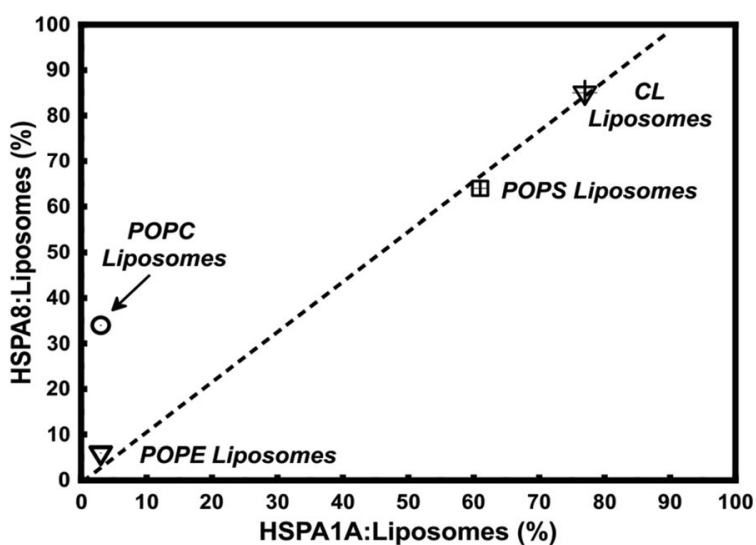

Fig. 2 HSPA 8 and HSPA1 interact preferentially with negatively charged liposomes. A HSPA8 $(4 \mu \mathrm{g})$ and B HSPA1A $(4 \mu \mathrm{g})$ were incubated with liposomes made of POPC, POPE, POPS, and CL (400 $\mu \mathrm{g}$ ) in $50 \mathrm{mM}$ Tris- $\mathrm{HCl}$ buffer ( $\mathrm{pH} 7.5$ ) for $30 \mathrm{~min}$ at $25^{\circ} \mathrm{C}$ with continuous agitation. The mixture was centrifuged at $100,000 \times g$ for $1 \mathrm{~h}$ at $4{ }^{\circ} \mathrm{C}$. The pellet was resuspended $(300 \mu \mathrm{L})$ in $100 \mathrm{mM} \mathrm{Na}_{2} \mathrm{CO}_{3}$ buffer $\mathrm{pH} 11.5$ and centrifuged at $100,000 \times g$ for $1 \mathrm{~h}$ at $4{ }^{\circ} \mathrm{C}$ in order to eliminate nonspecific bound proteins. Hsp70-liposomes were solubilized in sample buffer containing $10 \mathrm{mM} \beta-\mathrm{M}$, and the proteins were resolved by LDSPAGE and visualized by staining with Coomassie Brilliant Blue R-250. The total amount of protein used for the analysis is indicated by all
POPS liposomes did not affect HSPA8 and HSPA1A secondary and local tertiary structures (Fig. 2D and E, respectively).

\section{HSPA8 net charge modulates the interaction with liposomes}

We investigated whether the net charge of HSPA8 may influence the interaction with phospholipids. HSPA8 has 95 negative, and 82 positive amino acids spread across its structure. We incubated HSPA8 with POPS or CL liposomes in $50 \mathrm{mM}$ Tris$\mathrm{HCl}$ buffer ( $\mathrm{pH} 7.5$ ), $50 \mathrm{mM}$ Tris- $\mathrm{HCl}$ buffer ( $\mathrm{pH} 9.0$ ), or

d

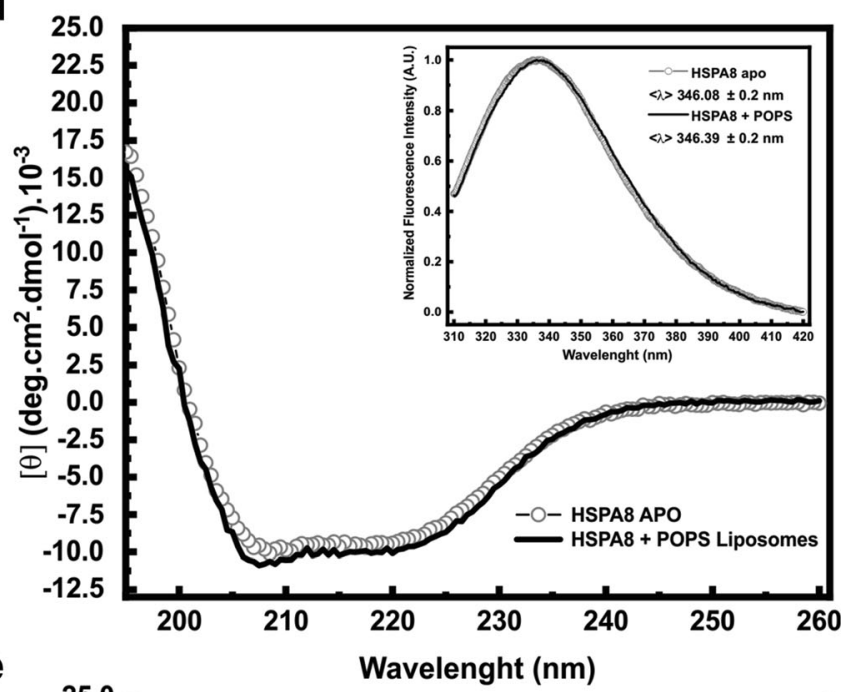

e

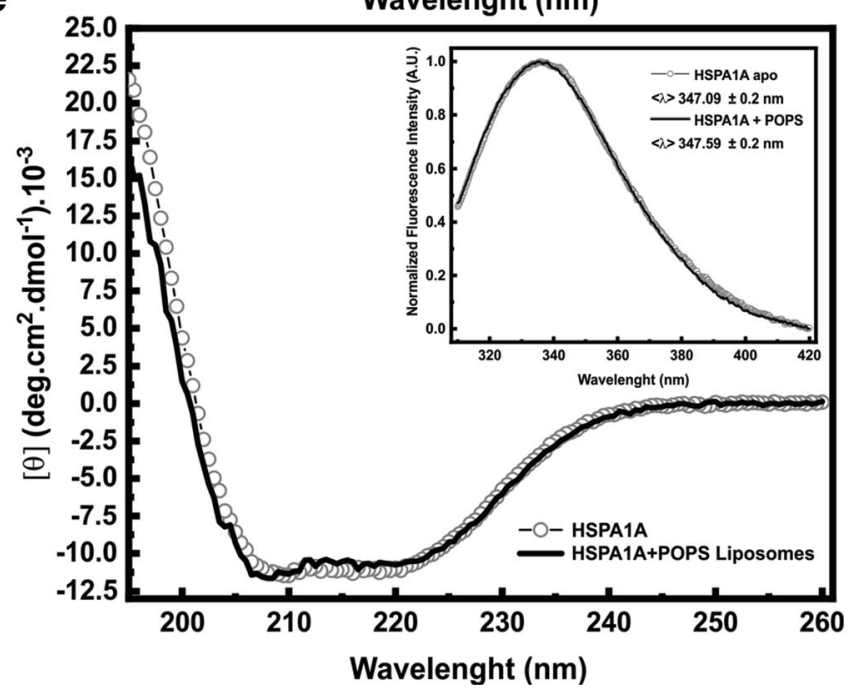

negative signals on the figure legend, whereas the amount of protein incorporated into the liposomes is indicated by the positive signal for each type of phospholipid. C The GelQuant software (http:// biochemlabsolutions.com/GelQuantNET.html) was used to estimate the intensity of bands in the gel and the percentage of HSPA8 or HSPA1A incorporated into the liposomes as expressed by a plot for the comparison for insertion of both proteins. D, E Protein secondary and tertiary structures were assessed by circular dichroism and intrinsic tryptophan fluorescence (insets) as described under Methods and did not shown variations in Hsp70s APO or binding into POPS liposomes 
$50 \mathrm{mM}$ acetate buffer $(\mathrm{pH}=5.0)$ for $30 \mathrm{~min}$ at $25{ }^{\circ} \mathrm{C}$ with continuous agitation and the incorporation of the protein into liposomes was monitored by LDS-PAGE. We observed an increment in the incorporation of HSPA8 into POPS liposomes $(95 \%)$ at $\mathrm{pH} 5.0$ in comparison with the incubation at $\mathrm{pH} 7.5$ $(65 \%)$. In contrast, there was a decrease of $50 \%$ when HSPA8 was incubated with POPS liposomes at $\mathrm{pH} 9.0$ with respect to incubation at $\mathrm{pH} 7.5$ (Fig. 3A, left panel). Similar observations were made after incubation with CL liposomes, indicating $87 \%$ incorporation at $\mathrm{pH} 5.0$ versus $78 \%$ at $\mathrm{pH} 7.5$ and a decrease in association at pH 9.0 (Fig. 3A, right panel). An analysis of the net charge of HSPA8 at the respective $\mathrm{pHs}$ indicated that the net protein charge is positive at $\mathrm{pH} 5.0(+20)$ and negative $(-14)$ for $\mathrm{pH} 7.5$ and $(-20)$ for $\mathrm{pH} 9.0$. Thus, the increase in PS/CL liposome incorporation at $\mathrm{pH} 5.0$ correlates with a net positive charge for the protein at this $\mathrm{pH}$ (Fig. 3B, Table 1). Under all the experimental conditions, POPS (pKa 2.6) presents a negative charge (Ionization Constants of Phospholipids | Avanti Polar Lipids (avantilipids.com). In contrast, there were no significant changes in HSPA8 incorporation into POPC liposomes at various pHs.

\section{The interaction of HSPA8 with liposomes made with negatively charged phospholipids is driven by entropy and enthalpy}

Isothermal titration calorimetry experiments were conducted to evaluate the HSPA8 interaction with POPS (Fig. 4A) or CL

a

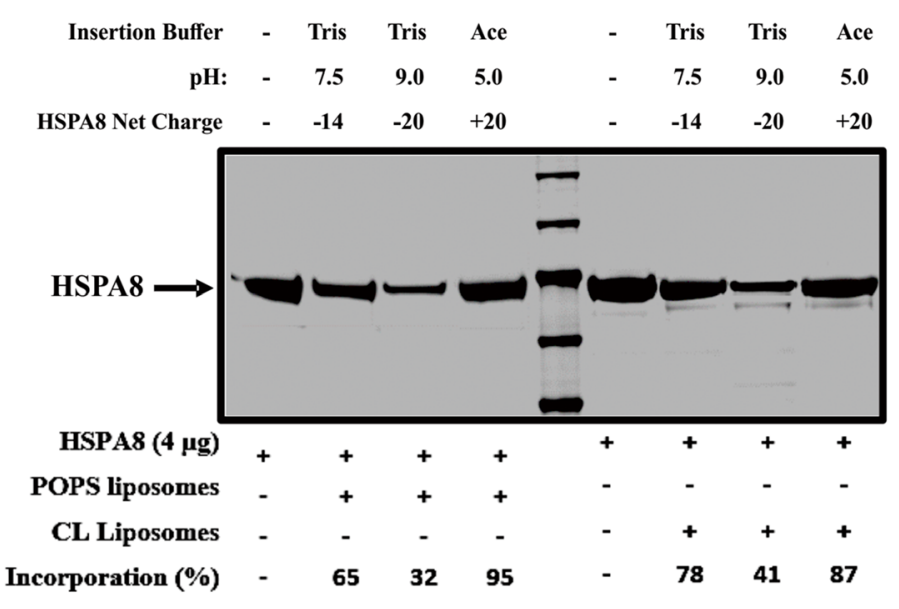

Fig. 3 HSPA8 interaction with negatively charged phospholipids is influenced by the protein net charge. A HSPA8 $(4 \mu \mathrm{g})$ was incubated with POPS or CL liposomes $(400 \mu \mathrm{g})$ in $50 \mathrm{mM}$ Tris-HCl buffer ( $\mathrm{pH} 7.5)$, $50 \mathrm{mM}$ Tris- $\mathrm{HCl}$ buffer ( $\mathrm{pH} 9.0)$, or $50 \mathrm{mM}$ acetate buffer $(\mathrm{pH}=5.0)$ for $30 \mathrm{~min}$ at $25^{\circ} \mathrm{C}$ with continuous agitation. The mixture was centrifuged at $100,000 \times g$ for $1 \mathrm{~h}$ at $4{ }^{\circ} \mathrm{C}$. The pellet was resuspended $(300 \mu \mathrm{L})$ in $100 \mathrm{mM} \mathrm{Na}_{2} \mathrm{CO}_{3}$ buffer $\mathrm{pH} 11.5$ and centrifuged at $100,000 \times \mathrm{g}$ for $1 \mathrm{~h}$ at $4{ }^{\circ} \mathrm{C}$. HSPA8 liposomes were solubilized in sample buffer containing $10 \mathrm{mM} \beta \mathrm{M}$, and the proteins were resolved by LDS-PAGE and visualized by staining with Coomassie Brilliant Blue R-250. The GelQuant
Table 1 Hsp70s net charge variation with $\mathrm{pH}$

\begin{tabular}{llllll}
\hline Hsp70/parameter & Dnak* & HSPA1A & HSPA5 & HSPA8 & HSPA9 \\
\hline Isoelectric point & 5.1 & 5.7 & 5.3 & 5.6 & 5.7 \\
Charge at pH 2.0 & +84 & +87 & +92 & +80 & +87 \\
Charge at pH 5.0 & +0.5 & +26 & +12 & +20 & +28 \\
Charge at pH 7.4 & -30 & -12 & -22 & -14 & -10 \\
Charge at pH 9.0 & -34 & -18 & -28 & -20 & -14 \\
Charge at pH 11.0 & -81 & -55 & -75 & -62 & -56 \\
\hline
\end{tabular}

*Hsp70 from Escherichia coli (strain K12)

liposomes (Fig. 4B). The thermodynamic signatures for HSPA8 association with POPS and CL indicated that the interactions have a discrete apparent enthalpy contribution $\left(\Delta \mathrm{H}_{\text {app }}=-=400 \pm 30 \mathrm{cal} \mathrm{mol}^{-1}\right.$ and $-\mathrm{a} 380 \pm 20 \mathrm{cal} \mathrm{mol}^{-1}$ for POPS and CL liposomes, respectively), while a much larger input of entropy $\left(-\mathrm{T} \Delta \mathrm{S}_{\mathrm{app}}=-=6100 \pm 300 \mathrm{cal} \mathrm{mol}^{-1}\right.$ and $-\mathrm{a} 5700 \pm 400 \mathrm{cal} \mathrm{mol}^{-1}$ for POPS and CL liposomes, respectively) (Fig. 4C). The dissociation constant was $17 \mu \mathrm{M}$ for the interaction with POPS liposomes and $33 \mu \mathrm{M}$ for CL liposomes. The $\Delta \mathrm{G}_{\text {app }}$ was $-\mathrm{w} 6500 \pm 300 \mathrm{cal} \mathrm{mol}^{-1}$ for POPS liposomes, and $-\mathrm{f} 6100 \pm 400 \mathrm{cal} \mathrm{mol}^{-1}$ for CL liposomes. Similar results have been reported for the interaction of HSPA1, HSPA5, and HSPA9 for POPS liposomes. In contrast, the interaction of HSPA8 with CL liposomes was similar to the one observed for HSPA1A and HSPA5 (Dores-Silva et al. 2020a), but different from the one obtained

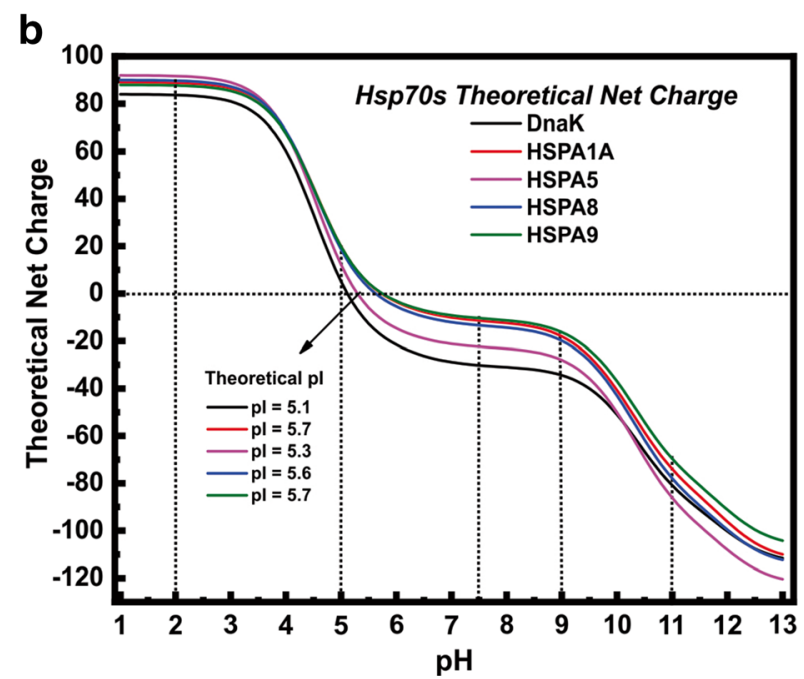

software (http://biochemlabsolutions.com/GelQuantNET.html) was used to estimate the percentage of HSPA8 incorporated into the liposomes. The results showed an increment of the HSPA8 incorporation in POPS (65 to $95 \%$ ) and CL liposomes (78 to $87 \%$ ) at $\mathrm{pH} 5.0$, and a decrease $(50 \%)$ at $\mathrm{pH} 9.0$. B The total net charge of the HSPA8 at various $\mathrm{pHs}$ over the isoelectric point ( $\mathrm{pH}$ 5.6) was calculated. These data suggest that the HSPA8 charge surface plays an important role in its interaction into liposomes made with negatively charged phospholipids 

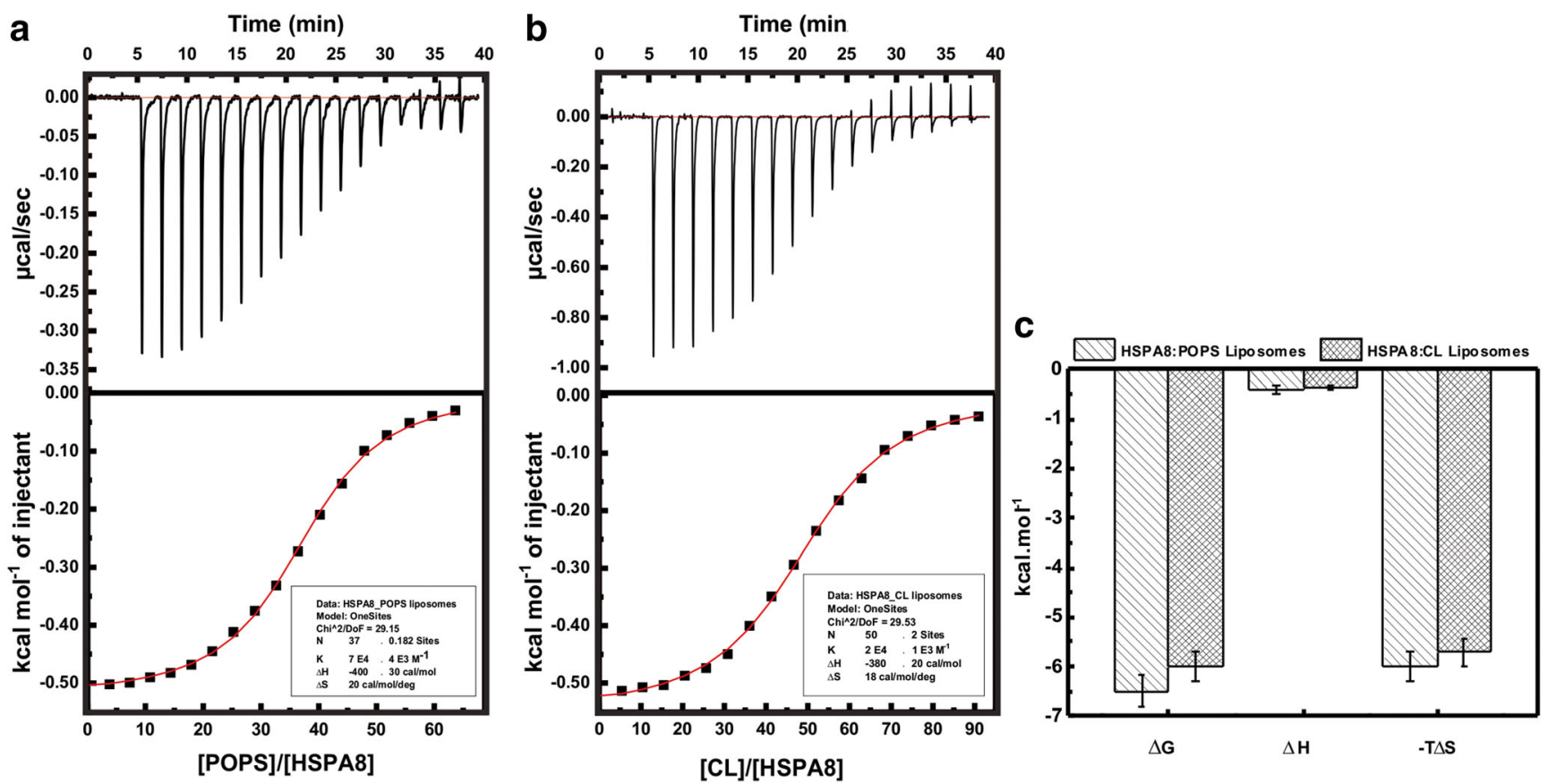

Fig. 4 HSPA8 interaction with POPS and CL liposomes is driven by entropic changes with a small enthalpy contribution. Thermodynamic parameters and dissociation constants were obtained by ITC as described under Methods using an iTC200 microcalorimeter. Seventeen $2-\mu \mathrm{L}$ aliquots of POPS or CL liposomes at $3 \mathrm{mM}$ were injected into 203.8 $\mu \mathrm{L}$ of $10-15 \mu \mathrm{mol} \mathrm{L}{ }^{-1} \mathrm{HSPA} 8$, at $25^{\circ} \mathrm{C}$. The pure protein was dialyzed to exhaustion against $50 \mathrm{mM}$ Tris- $\mathrm{HCl}$ (pH 7.4) buffer, and the liposomes were prepared in the dialyze buffer to avoid mismatch. The experimental

for HSPA9 that was enthalpically unfavorable and entropically driven (Dores-Silva et al. 2020b).

In order to better understand the interaction of various HSP70s with POPS or -CL liposomes, we generated a scatter

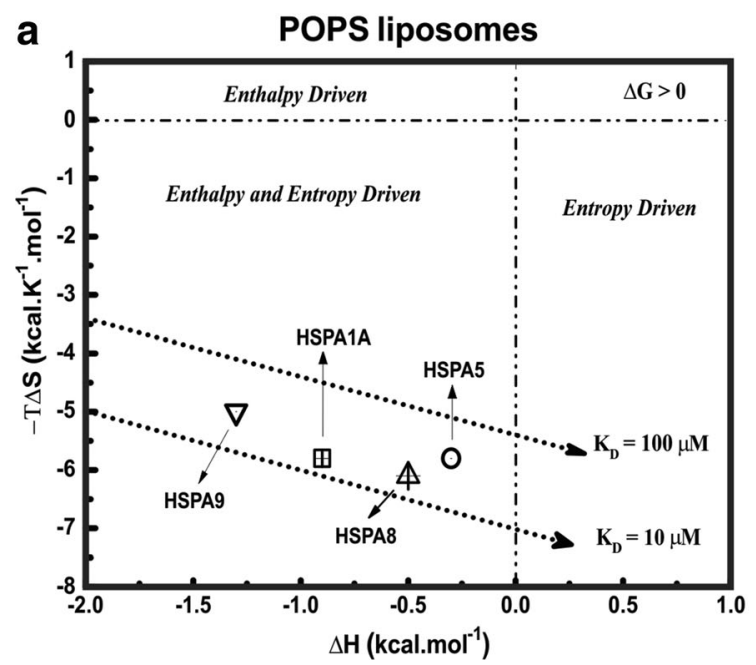

Fig. 5 Human Hsp70s interaction with liposomes made with negatively charged lipids present a slightly different interaction mechanism. Scatter plot of $-\mathrm{T} \Delta \mathrm{S}$ against $\Delta \mathrm{H}$ for the interaction of HSPA1A, HSPA5, HSPA8, and HSPA9 with POPS (A) and CL (B) liposomes. The double dashed lines indicate the points representing possible combinations of $\Delta \mathrm{H}$ and $-\mathrm{T} \Delta \mathrm{S}$ values giving rise to the two different equilibrium constants indicated $\left(\mathrm{K}_{\mathrm{D}}=10 \mu \mathrm{M}\right.$ and $\left.\mathrm{K}_{\mathrm{D}}=100 \mu \mathrm{M}\right)$. All the human Hsp70s, isotherm curves were analyzed to obtain the $\Delta \mathrm{G}_{\mathrm{app}}, \Delta \mathrm{H}_{\mathrm{app}},-\mathrm{T} \Delta \mathrm{S}_{\mathrm{app}}$, and $\mathrm{K}_{\mathrm{D}}$. A HSPA8 interaction with POPS liposomes. B HSPA8 interaction with CL liposomes. The HSPA8 insertion into liposomes was entropically and enthalpically driven, with a higher entropic contribution. C Thermodynamic signatures for HSPA8 interaction with POPS and CL show that the interaction has a very discrete enthalpy contribution, and it is pretty much entropically driven

plot of $-\mathrm{T} \Delta \mathrm{S}$ versus $\Delta \mathrm{H}$ for HSPA1A, HSPA5, HSPA8, and HSPA9 with the above-referred phospholipids (Fig. 5A and B, for POPS or CL, respectively), based on the current and published thermodynamic signatures (Dores-Silva et al. 2020a,

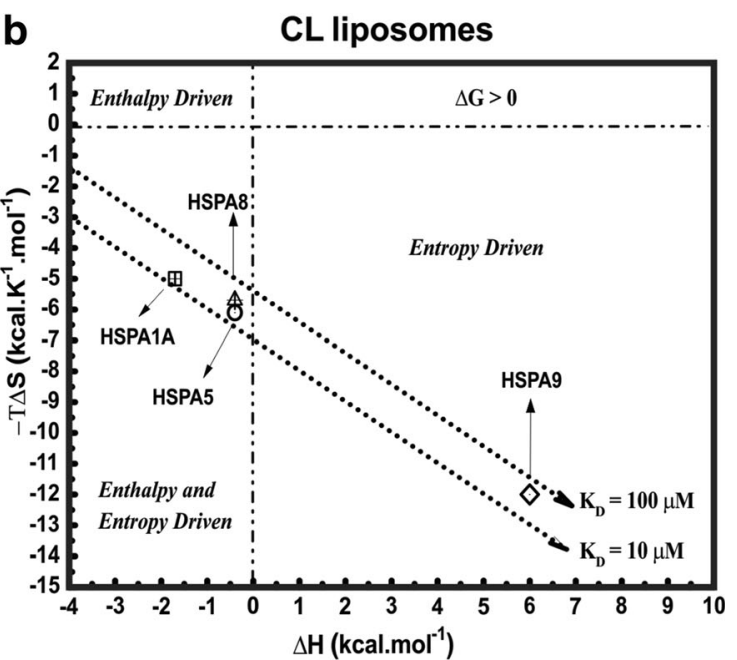

constitutive (HSPA5, HSPA8, and HSPA9) and inducible Hsp70 (HSPA1A), interact with POPS and CL liposomes with similar $\mathrm{K}_{\mathrm{D}}$ and consequently $\Delta \mathrm{G}$. However, the mechanism for each interaction is slightly different, involving different levels of intramolecular (such as hydrogen-bound) and hydrophobic interactions, water release, and conformational changes 
2020b). The two dashed lines indicate the loci of the points representing possible combinations of $\Delta \mathrm{H}_{\mathrm{app}}$ and $-\mathrm{T} \Delta \mathrm{S}_{\mathrm{app}}$ values giving rise to the two different equilibrium constants $\left(\mathrm{K}_{\mathrm{D}}=10 \mu \mathrm{M}\right.$ and $\left.\mathrm{K}_{\mathrm{D}}=100 \mu \mathrm{M}\right)$. All HSPAs, constitutive (HSPA5, HSPA8, and HSPA9) and inducible (HSPA1A), interacted with POPS and CL liposomes with similar $K_{D}$ and consequently apparent $\Delta \mathrm{G}$ values. However, the possible mechanisms for each interaction were slightly variable, involving different levels of intramolecular interactions such as hydrogenbound and Van der Waals forces as well as hydrophobic interactions, water displacement, and conformational changes.

\section{HSPA8 is indeed inserted into the lipid bilayer of POPS liposomes}

In order to establish whether HSPA8 association with POPS liposomes resulted in a peripheral interaction or the incorporation into the lipid bilayer, we treated the liposomes with proteinase $\mathrm{K}$ after incubation of the protein. HSPA8 was incubated with POPS liposomes, the non-incorporated protein was released by ultracentrifugation, and the resulting proteoliposomes were incubated with proteinase $\mathrm{K}$ at $25^{\circ} \mathrm{C}$ for $1 \mathrm{~h}$. Then, liposomes were pelleted by ultracentrifugation, solubilized, separated by LDS-PAGE, and visualized by staining with Coomassie Brilliant Blue R-250. Upon incubation with proteinase $\mathrm{K}$, two peptides of molecular mass $42 \mathrm{kDa}$ and $27 \mathrm{kDa}$ were detected within the liposomes (Fig. 6, line 4), indicating that they were protected from protease digestion and retained within the liposomes corresponding to portions of HSPA8 that were embedded into the liposomes. As a control, HSPA8 was incubated with proteinase $\mathrm{K}$ in the absence of liposomes that resulted in complete degradation (Fig. 6, line 2).

\section{HSPA8 oligomerizes upon membrane interaction via disulfide bonds}

We have previously shown that HSPA5 and HSPA1A oligomerized upon insertion into POPS and CL liposomes mediated by the formation of disulfide bonds (Dores-Silva et al. 2020a). In order to evaluate whether or not the HSPA8 also forms disulfide bonds upon membrane insertion and oligomerization, the protein was incubated with the liposomes as described in Methods, and liposome incorporation was determined by LDS-PAGE in the presence or absence of $\beta-\mathrm{M}$ addition. Indeed, oligomers were detected after incorporation into POPS or CL liposomes only in the absence of $\beta \mathrm{M}$ addition suggesting the formation of disulfide bonds (Fig. 7).

\section{HSPA8 interaction with POPS and CL liposomes is hindered by ATP or ADP}

We also tested whether the interaction of HSPA8 with POPS or CL liposomes was affected by the presence of ATP or

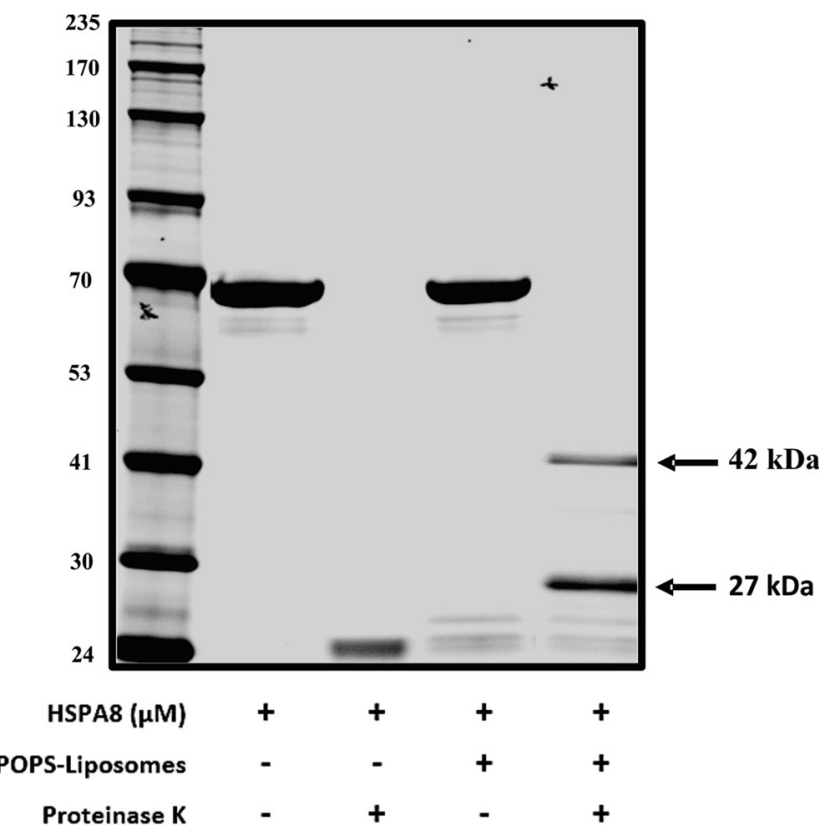

Fig. 6 HSPA8 is inserted into POPS lipid bilayer. HSP8 $(4 \mu \mathrm{g})$ was incubated with POPS liposomes $(400 \mu \mathrm{g})$ in $50 \mathrm{mM}$ Tris- $\mathrm{HCl}$ buffer (pH 7.5) for $30 \mathrm{~min}$ at $25^{\circ} \mathrm{C}$ with continuous agitation. The mixture was centrifuged at $100,000 \times g$ for $1 \mathrm{~h}$ at $4{ }^{\circ} \mathrm{C}$. The pellet was resuspended $(300 \mu \mathrm{L})$ in $100 \mathrm{mM} \mathrm{Na}_{2} \mathrm{CO}_{3}$ buffer $\mathrm{pH} 11.5$ and centrifuged again at $100,000 \times g$ for $1 \mathrm{~h}$ at $4{ }^{\circ} \mathrm{C}$. The pellet was resuspended in $50 \mathrm{mM}$ Tris$\mathrm{HCl}$ buffer $\mathrm{pH} 7.5$ and incubated with proteinase $\mathrm{K}\left(5 \mu \mathrm{g} \mathrm{mL}{ }^{-1}\right)$ for $30 \mathrm{~min}$ at $25^{\circ} \mathrm{C}$ and centrifuged for $1 \mathrm{~h}$ at $100,000 \times \mathrm{g}$. The pellet was solubilized in sample buffer containing $10 \mathrm{mM} \beta \mathrm{M}$, and the proteins were resolved by LDS-PAGE and visualized by staining with Coomassie Brilliant Blue R-250. Brackets indicate low molecular weight peptides retained within the liposomes after protease digestion

ADP. HSPA8 was incubated with POPS or CL liposomes in the absence or in the presence of ATP $(1 \mathrm{mM})$ or ADP $(1 \mathrm{mM})$ at $25{ }^{\circ} \mathrm{C}$ for $30 \mathrm{~min}$, and incorporation was determined by LDS-PAGE. An 8-fold decrease in the incorporation of HSPA8 into POPS or CL liposomes was observed in the presence of ATP or ADP, suggesting that the conformational changes upon nucleotide binding may disturb the association with the phospholipids (Fig. 8A and B).

\section{HSPA8 drags HSP90AA1 into the POPS and CL liposomes}

We have previously found that HSP90AA1 did not interact with POPS (Armijo et al. 2014). However, several studies have detected the presence of HSP90 on the surface of various cell types (Ferrarini et al. 1992; Camins et al. 1999; Kakimura et al. 2002; Tsutsumi and Neckers 2007; Fong-Ngern et al. 2016; Lauwers et al. 2018). Moreover, other studies have reported the association of Hsp90 (Hsp90AA1) with membranes containing unsaturated and negatively charged phospholipids and cholesterol (Zhang et al. 2018). In order to investigate the possible origin of these conflicting results, we 


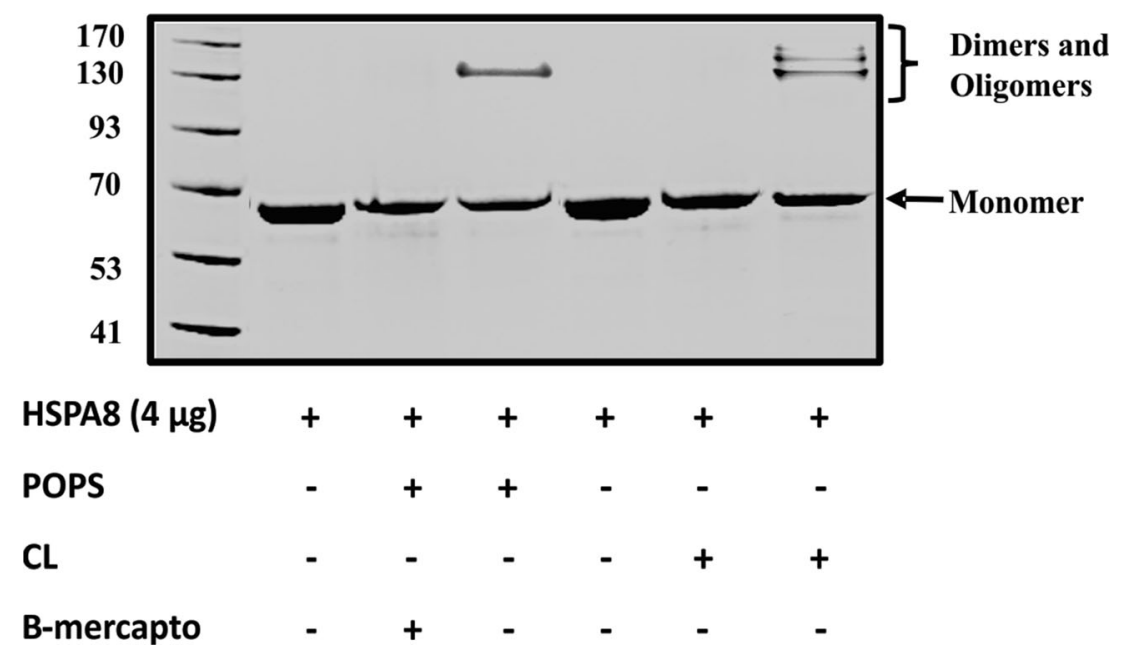

Fig. 7 HSPA8 oligomerizes upon membrane insertion into POPS or CL liposomes. HSP8 $(4 \mu \mathrm{g})$ were incubated with POPS or CL liposomes $(400 \mu \mathrm{g})$ in $50 \mathrm{mM}$ Tris- $\mathrm{HCl}$ buffer $(\mathrm{pH} 7.5)$ for $30 \mathrm{~min}$ at $25^{\circ} \mathrm{C}$ with continuous agitation. The mixture was centrifuged at $100,000 \times g$ for $1 \mathrm{~h}$ at $4{ }^{\circ} \mathrm{C}$. The pellet was resuspended $(300 \mu \mathrm{L})$ in $100 \mathrm{mM} \mathrm{Na}_{2} \mathrm{CO}_{3}$ buffer $\mathrm{pH}$
11.5 and centrifuged again at $100,000 \times g$ for $1 \mathrm{~h}$ at $4{ }^{\circ} \mathrm{C}$. The pellet was solubilized in sample buffer containing or not $10 \mathrm{mM} \beta \mathrm{M}$, and the proteins were resolved by LDS-PAGE and visualized by staining with Coomassie Brilliant Blue R-250. The brackets indicate the presence of oligomers
Fig. 8 The insertion of HSPA8 into POPS or CL liposomes is decreased by the addition of ATP or ADP. HSP8 $(4 \mu \mathrm{g})$ was incubated with POPS (A) or CL (B) liposomes $(400 \mu \mathrm{g})$ in $50 \mathrm{mM}$ Tris-HCl buffer ( $\mathrm{pH} 7.5$ ) for $30 \mathrm{~min}$ at $25^{\circ} \mathrm{C}$ in the presence or absence of ATP $(1 \mathrm{mM})$ or ADP $(1 \mathrm{mM})$. The mixture was centrifuged at $100,000 \times g$ for $1 \mathrm{~h}$ at 4 ${ }^{\circ} \mathrm{C}$. The pellet was resuspended $(300 \mu \mathrm{L})$ in $100 \mathrm{mM} \mathrm{Na}_{2} \mathrm{CO}_{3}$ buffer $\mathrm{pH} 11.5$ and centrifuged again at $100,000 \times \mathrm{g}$ for $1 \mathrm{~h}$ at $4{ }^{\circ} \mathrm{C}$. The pellet was solubilized in sample buffer containing or not $10 \mathrm{mM} \beta \mathrm{M}$, and the proteins were resolved by LDS-PAGE and visualized by staining with Coomassie Brilliant Blue R-250 a

POPS Liposomes

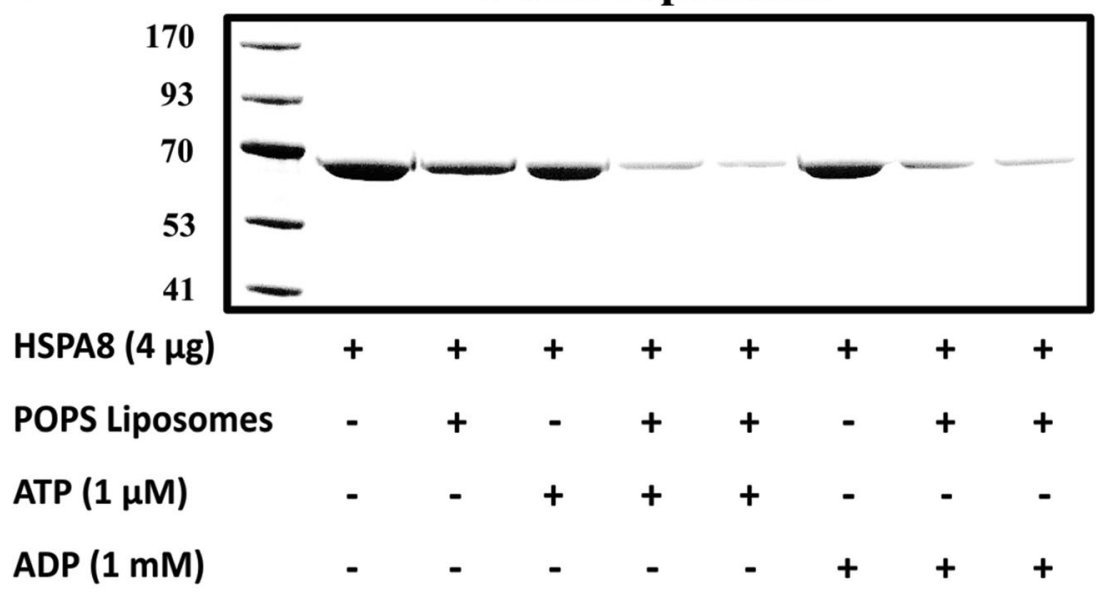

b

CL Liposomes

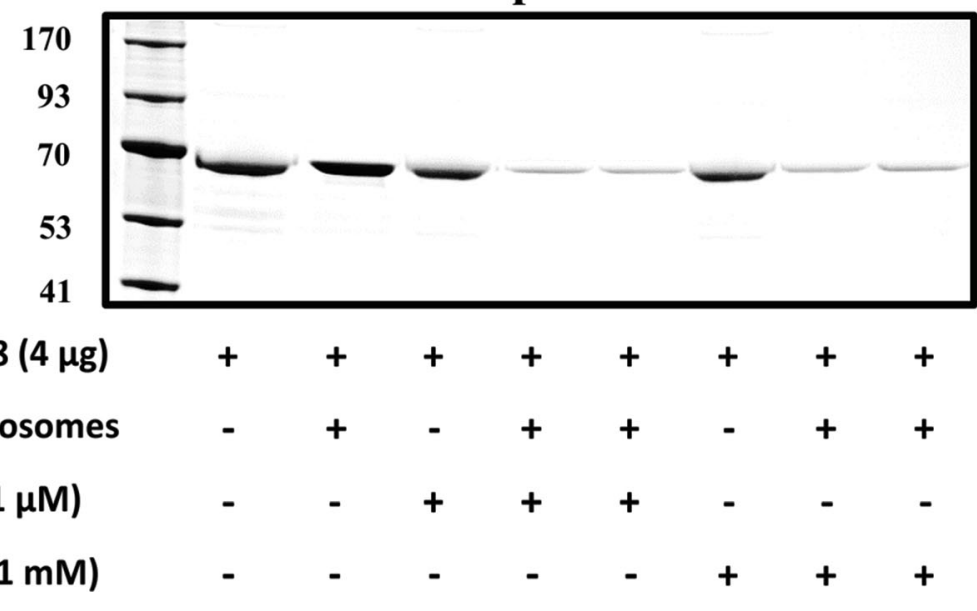


hypothesize that the interaction of HSP90 with membranes may be mediated by the presence of an additional protein. In order to test this possibility, HSP90AA1 $(3 \mu \mathrm{g})$ was incubated or not with HSPA8 $(4 \mu \mathrm{g})$ for $30 \mathrm{~min}$ at $25{ }^{\circ} \mathrm{C}$. Then, the mixture of the two proteins was incubated with POPS or CL liposomes $(400 \mu \mathrm{g})$ in $50 \mathrm{mM}$ Tris- $\mathrm{HCl}$ buffer $(\mathrm{pH} 7.5)$ for $30 \mathrm{~min}$ at $25^{\circ} \mathrm{C}$ with continuous agitation. The final material was separated and analyzed by LDS-PAGE. Indeed, we observed that HSP90AA1 was present within the liposomes when co-incubated with HSPA8 (Fig. 9A and B, line 6), whereas HSP90AA1 did not get inserted into either POPS or CL liposomes in absence of HSPA8 (Fig. 9A and B, line 3). This ability of HSPA8 to mediate HSP90AA1 membrane interaction was specific since incubation of green fluorescent protein (GFP) with HSPA1A did not result in GFP liposome association. At this moment, it is unclear whether the presence of HSP90AA1 within liposomes is due to binding to the membrane bound to HSPA8 or inserted into the lipid bilayer. Nevertheless, these observations suggest that HSPA8 may drag HSP90AA1 into the liposomes, perhaps acting as a membrane chaperone.

\section{Discussion}

The HSP70 family of proteins is composed of several members localized within different subcellular compartments where they play diverse functions directed at conserving homeostasis and protecting from harmful conditions (De Maio 1999; Hartl and Hayer-Hartl 2002). A remarkable characteristic of these proteins is their ability to interact with lipid membranes that has been postulated to confer stability to the lipid bilayer (Balogi et al. 2019). In addition, HSP70 (HSPA1) and GRP78 (HSPA5) are present on the surface of cells, particularly those of cancerous nature (Multhoff and Hightower 2011; Shevtsov et al. 2020; Pfaffenbach and Lee 2011). Moreover, HSPA5 have been reported as potential receptor for several viruses, including Borna disease (Honda et al. 2009), Coxsackie, dengue virus serotype 2, Japanese encephalitis (Kottom et al. 2018), SARS-CoV-1 (Chu et al. 2018), and SARS-CoV-2 (Ibrahim et al. 2020). Recently, GRP78 was found to form a complex with the angiotensinconverting enzyme 2 and associate with the SARS-CoV-2 spike protein (Carlos et al. 2021).

All HSP70s contain two well-defined domains, one responsible for nucleotide binding (NBD) within the Nterminal end of proteins and a second within the $\mathrm{C}$-terminus end that provides a pocket for protein substrate binding (SBD). These two domains are interconnected by a short hydrophobic linker. The protein displays a major conformational change upon substrate and nucleotide binding (Fig. 10) (Mayer et al. 2001; da Silva and Borges 2011). The major constitutive cytosolic member of the HSP70 family is heat shock cognate protein or HSPA8, also referred to as HSP73 (De Maio 1999). This protein displays about $86 \%$ identity with the major inducible HSP70 (HSPA1), 65\% with HSPA5, and 50\% with bacterial HSP70 (DnaK). HSPA8 was initially found associated with fatty acids during the final step in its purification (Guidon Jr. and Hightower 1986a, 1986b). HSPA8 has been previously reported to get spontaneously inserted into lipid bilayers forming very stable ion conductance channels (Arispe and De Maio 2000; Macazo and White 2014), similar to HSPA1 (Vega et al. 2008). Although both HSPA8 and HSPA1 showed similar ion conductance activities, their interaction with lipid membranes was different, as documented in a liposome aggregation assay, a

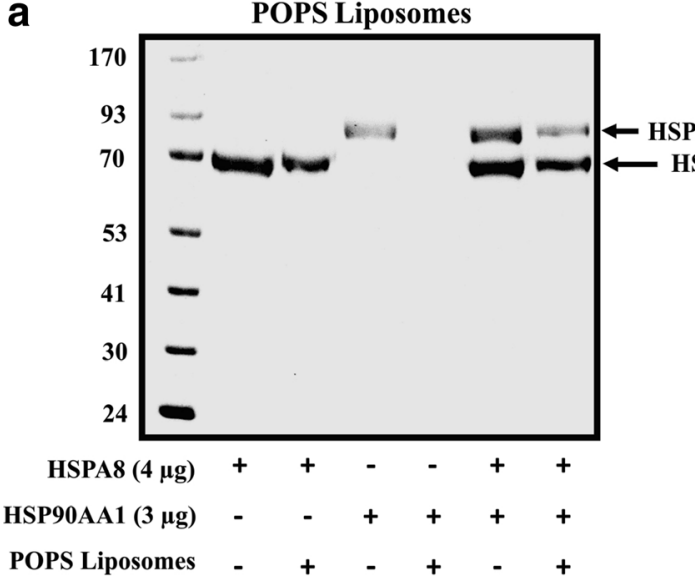

Fig. 9 HSPA8 drags HSP90 into POPS and CL liposomes. HSP8 $(4 \mu \mathrm{g})$ and HSP90AA1 $(3 \mu \mathrm{g})$ were incubated at $25{ }^{\circ} \mathrm{C}$ for $30 \mathrm{~min}$. Then, the mixture was incubated with POPS (A) or CL (B) liposomes $(400 \mu \mathrm{g})$ in $50 \mathrm{mM}$ Tris-HCl buffer ( $\mathrm{pH} 7.5$ ) for $30 \mathrm{~min}$ at $25^{\circ} \mathrm{C}$ with continuous agitation. The mixture was centrifuged at $100,000 \times g$ for $1 \mathrm{~h}$ at $4{ }^{\circ} \mathrm{C}$. The pellet was resuspended $(300 \mu \mathrm{L})$ in $100 \mathrm{mM} \mathrm{Na}_{2} \mathrm{CO}_{3}$ buffer $\mathrm{pH} 11.5$ and b

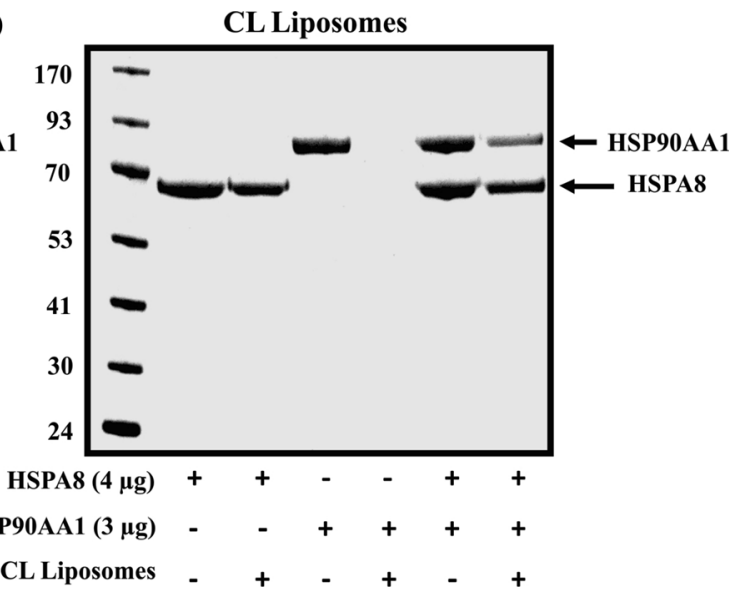

centrifuged again at $100,000 \times g$ for $1 \mathrm{~h}$ at $4{ }^{\circ} \mathrm{C}$. The pellet was solubilized in sample buffer containing or not $10 \mathrm{mM} \beta \mathrm{M}$, and the proteins were resolved by LDS-PAGE and visualized by staining with Coomassie Brilliant Blue R-250. Notice that HSP90AA1 is only present within liposomes after incubation with HSPA8, suggesting membrane chaperone activity 
Fig. 10 Conformational changes of HSPA8 in the presence of nucleotides. A homology model for HSPA8 (1-646 a.a.) in the closed and open states was obtained using the Swiss-Model program (SWISS-MODEL

(expasy.org). For closed state, the PDBs templates 3C7N.1.B (HSPA8 covered 1-554 a.a. with $100 \%$ of identity) and 2KHO.1.A (HSPA8 covered 1-612 a.a. with $50 \%$ of identity) were employed. For open conformation, the templates used were 6ASY.1.A (HSPA8 covered 1-606 a.a. with $66 \%$ of identity). The same online tool was also used to generate the HSPA8 N-terminal models (1401 a.a.). The model in the presence of ATP was generated using the PDB template 6ASY.1.A (HSP8 N-terminal covered 1-401 a.a. with $71 \%$ of identity) and for the model in the presence of ADP, the PDB template was used: 3FE1.1.A (HSP8 N-terminal covered $1-401$ a.a. with $83 \%$ of identity)
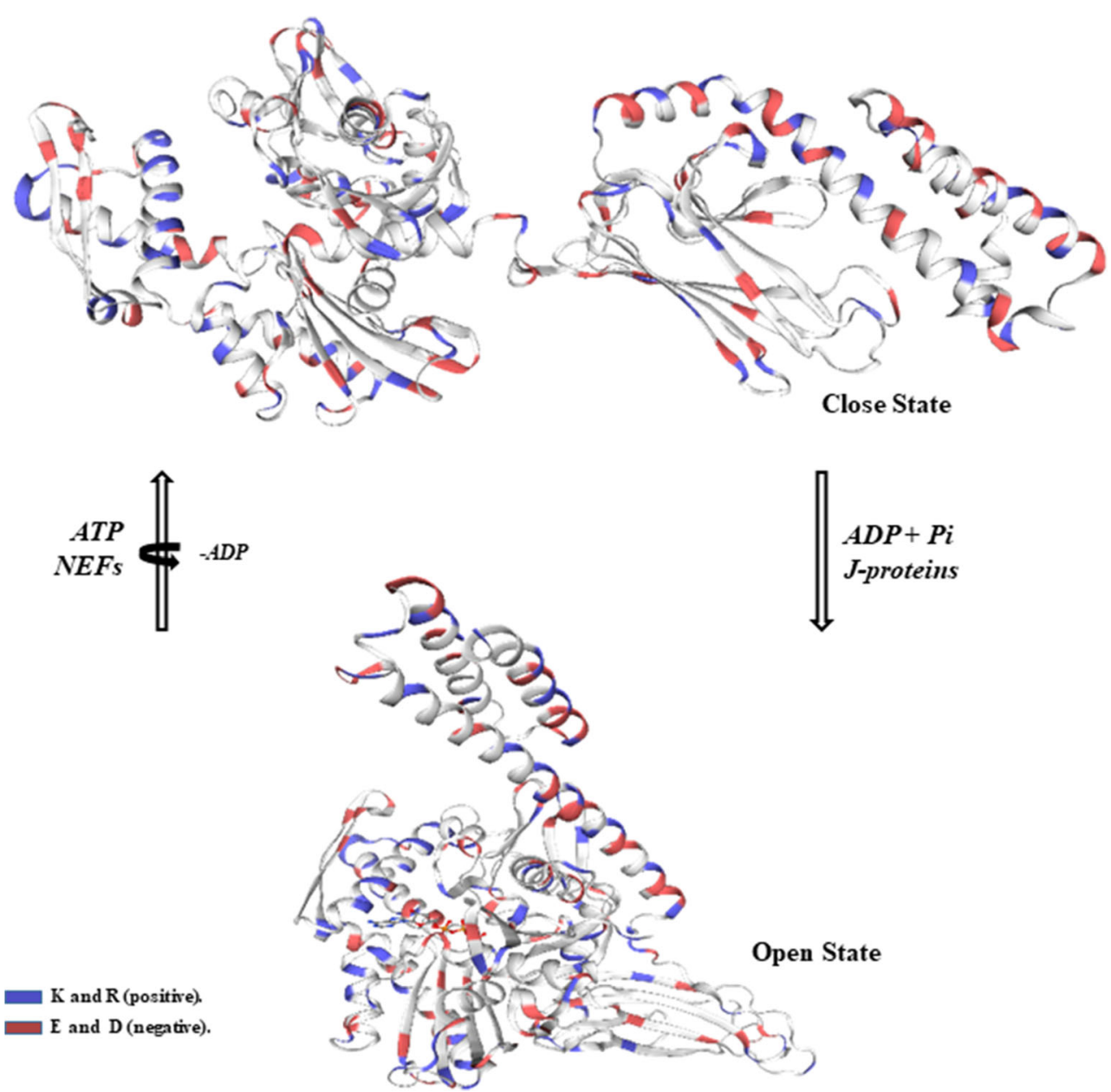

displaying differences in insertion kinetics and the effects of calcium and nucleotides (Arispe et al. 2002).

In the present study, we have further characterized the association of HSPA8 with lipid membranes using a liposome assay. HSPA8 showed high selectivity for negatively charged phospholipids (PS and CL), which echoes prior studies for HSPA1, HSPA5, and HSPA9 (Arispe et al. 2004; Schilling et al. 2009; Armijo et al. 2014; Dores-Silva et al. 2020a, 2020b). However, HSPA8 also presented a low-affinity activity with PC that was not observed for other HSP70 members (Armijo et al. 2014; Dores-Silva et al. 2020a, 2020b), except for DnaK (Lopez et al. 2016). Structural studies suggest that there is no change in the secondary and local tertiary structure of HSPA8 or HSPA1A after interaction into POPS or CL liposomes (Fig. 2D and E). Thermodynamic parameters for the interaction of HSPA8 with POPS and CL liposomes indicated that the process was spontaneous and mainly driven by entropy changes. A comparison of $-\mathrm{T} \Delta \mathrm{S}$ and $\Delta \mathrm{H}$ values for the interaction of all HSP70s with POPS liposomes suggests that each one of them presents a slightly different mechanism for membrane insertion that involved intramolecular interactions, Van der Waals forces, hydrophobic interactions, water displacements, and conformational changes (Fig. 5A). In contrast, the interaction with CL liposomes is similar between HSPA8 and HSPA5 and different from HSPA1 and HSPA9 (Fig. 5B). These observations confirmed that the interaction of all HSP70 members with lipid membranes is not identical in spite of their tremendous selectivity for negatively charged phospholipids and sequence identity.

A very interesting observation is that the interaction of HSPA8 with POPS or CL liposomes is dependent on the $\mathrm{pH}$ of the incubation medium, with higher incorporation at $\mathrm{pH} 5$ and a reduction at $\mathrm{pH} 9$, suggesting that the net charge of the protein may play a role in the interaction with the phospholipids. HSPA8 sequence presents a random and homogeneous distribution of positive and negative charged amino acids on the protein surface, which is very similar to other HSP70 members. The net charge of HSPA8 is positive at $\mathrm{pH} 5.0$ and negative at $\mathrm{pH} 9.0$, suggesting that positive microenvironments on the surface of HSPA 8 may be involved in the interaction with the negatively charged phospholipid bilayer. Indeed, positive amino acids within the $\mathrm{N}$-terminus end of HSPA8 were reportedly involved in binding to PS on the cytosolic side of endosomes (Sahu et al. 2011; Morozova et al. 2016). The interaction of HSPA8 with the negative head of phospholipids is likely the first step for membrane insertion as 
postulated for the interaction of other proteins with lipid membranes, which may be followed by a conformational change that facilitates the incorporation into the most hydrophobic region of the membrane, which may be part or change of secondary structure or an oligomerization process (Wiener and White 1992; Wimley et al. 1998). Indeed, HSPA8 forms oligomeric complexes upon membrane insertion that are stabilized by intermolecular disulfide bonds. HSPA8 has four cysteine groups, two in the NBD and two in the SBD, that are likely involved in oligomerization process. It is likely that the phospholipid membrane provides the oxidated environment responsible for the formation of disulfide bridges. The oligomerization process may also display water molecules from the surface of the protein, increasing the entropy of the system as indicated by the thermodynamic parameters presented in this study. Prior investigations have shown that HSPA1 and HSPA5 also form oligomer complexes via intermolecular disulfide bridges in antiparallel conformation (Dores-Silva et al. 2020a). In spite of the increase in information regarding HSP70 membrane insertion, the precise mechanism by which a highly charged protein, without any major hydrophobic domains, gets incorporated into lipid bilayers remains unclear.

Another important observation is that the association of HSPA8 with liposomes is reduced by the presence of ATP or ADP. We hypothesize that in the presence of adenosine nucleotides, HSPA8 cannot freely move between the two main conformations, a process that may be necessary for interaction with the phospholipid head or membrane insertion. The $\Delta \mathrm{G}$ of the binding of HSPA8 to ATP or ADP is about -7 and $-9 \mathrm{kcal} \mathrm{mol}^{-1}$, respectively (Borges and Ramos 2006; Dores-Silva et al. 2015). On the other hand, the $\Delta G$ for the interaction of HSPA8 with POPS or CL liposomes is -6.2 and $-6 \mathrm{kcal} \mathrm{mol}^{-1}$, respectively. These differences in $\Delta \mathrm{G}$ suggest that association with adenosine nucleotides is preferred over the interaction with POPS or CL liposomes.

The main question that surfaces is regarding the function of the interaction of HSP70 with lipid membranes. Extensive studies by the Vigh's group have provided evidence that HSP70s stabilize membranes (Horvath et al. 2008; Torok et al. 2014; Balogi et al. 2019). Similarly, HSP70 association with lysosome via binding to bis(monoacylglycero)phosphate contributes to the stability of the membrane avoiding the leakage of degrading enzymes (Nylandsted et al. 2004; Kirkegaard et al. 2010; Mahalka et al. 2014). Other studies have proposed that the presence of HSP70 on the surface of cancer cells may support cell survival (Botzler et al. 1996; Multhoff et al. 2020). In addition, the translocation of HSP70 into the plasma membrane may be the earliest event for the export of these proteins into the extracellular milieu, which may be mediated via exosomes (De Maio 2011). Certainly, HSP70 has been detected on membrane blebs, a prerequisite for exosome release (Lamprecht et al. 2018), as well as on the membrane of these vesicles (Gastpar et al. 2005; Vega et al. 2008; Gobbo et al. 2016; Chanteloup et al. 2020). Finally, the capacity of HSP70 to associate with phospholipids and stabilize membranes could have been a key factor during the conversion of protocells into complex modern cellular membranes (De Maio and Hightower 2021). The intersection between stabilization of membranes and chaperone activity raises the possibility that HSP70s could be a chaperone, participating in the insertion of other proteins into membranes. In this regard, we found that HSP90, which does not display any membrane binding capacity, was inserted into liposomes upon co-incubation with HSPA8. We speculate that HSPA8 associates with HSP90 in solution and drives this protein into the lipid membrane. However, it is unclear whether HSP90 is inserted into the lipid bilayer or if it is peripherally bound to membrane HSPA8. This novel observation deserves further evaluation.

Acknowledgements This work was supported by National Institutes of Health (NIH) grants: R01 GM098455-04 and R01 GM114473-01, by the Fundação de Amparo à Pesquisa do Estado de São Paulo (FAPESP) grants (2012/50161-8, 2014/16646-0, 2016/22477-1, 2017/07335-9 and 2017/26131-5) and by Conselho Nacional de Pesquisa e Desenvolvimento (CNPq) grant (303262/2018-4).

\section{References}

Arispe N, De Maio A (2000) ATP and ADP modulate a cation channel formed by $\mathrm{Hsc} 70$ in acidic phospholipid membranes. J Biol Chem 275:30839-30843

Arispe N, Doh M, De Maio A (2002) Lipid interaction differentiates the constitutive and stress-induced heat shock proteins Hsc70 and Hsp70. Cell Stress Chaperones 7:330-338

Arispe N, Doh M, Simakova O, Kurganov B, De Maio A (2004) Hsc70 and Hsp70 interact with phosphatidylserine on the surface of PC12 cells resulting in a decrease of viability. FASEB J 18:1636-1645

Armijo $\mathrm{G}$ et al (2014) Interaction of heat shock protein 70 with membranes depends on the lipid environment. Cell Stress Chaperones 19:877-886

Balogh $\mathrm{G}$ et al (2013) Key role of lipids in heat stress management. FEBS Lett 587:1970-1980

Balogi Z et al (2019) Hsp70 interactions with membrane lipids regulate cellular functions in health and disease. Prog Lipid Res 74:18-30

Borges JC, Ramos CH (2006) Spectroscopic and thermodynamic measurements of nucleotide-induced changes in the human 70-kDa heat shock cognate protein. Arch Biochem Biophys 452:46-54

Botzler C, Issels R, Multhoff G (1996) Heat-shock protein 72 cell-surface expression on human lung carcinoma cells in associated with an increased sensitivity to lysis mediated by adherent natural killer cells. Cancer Immunol Immunother 43:226-230

Camins A, Diez-Fernandez C, Prieto P (1999) Cell-surface expression of heat shock proteins in dog neutrophils after oxidative stress. Toxicol in Vitro 13:437-443

Carlos RSA et al. (2021) First genome sequencing of SARS-CoV-2 recovered from an infected cat and its owner in Latin America. Transbound Emerg Dis [online ahead of print]

Chanteloup G, Cordonnier M, Isambert N, Bertaut A, Marcion G, Garrido C, Gobbo J (2020) Membrane-bound exosomal HSP70 as 
a biomarker for detection and monitoring of malignant solid tumours: a pilot study. Pilot Feasibility Stud 6:35

$\mathrm{Chu} \mathrm{H}$ et al (2018) Middle East respiratory syndrome coronavirus and bat coronavirus HKU9 both can utilize GRP78 for attachment onto host cells. J Biol Chem 293:11709-11726

da Silva KP, Borges JC (2011) The molecular chaperone Hsp70 family members function by a bidirectional heterotrophic allosteric mechanism. Protein Pept Lett 18:132-142

De Maio A (1999) Heat shock proteins: facts, thoughts, and dreams. Shock 11:1-12

De Maio A (2011) Extracellular heat shock proteins, cellular export vesicles, and the stress observation system: a form of communication during injury, infection, and cell damage. It is never known how far a controversial finding will go! Dedicated to Ferruccio Ritossa Cell Stress Chaperones 16:235-249

De Maio A, Hightower LE (2021) Heat shock proteins and the biogenesis of cellular membranes. Cell Stress Chaperones 26:15-18

Dores-Silva PR, Silva ER, Gomes FE, Silva KP, Barbosa LR, Borges JC (2012) Low resolution structural characterization of the Hsp70interacting protein - Hip - from Leishmania braziliensis emphasizes its high asymmetry. Arch Biochem Biophys 520:88-98

Dores-Silva PR, Barbosa LR, Ramos CH, Borges JC (2015) Human mitochondrial Hsp70 (mortalin): shedding light on ATPase activity, interaction with adenosine nucleotides, solution structure and domain organization. PLoS One 10:e0117170

Dores-Silva PR, Cauvi DM, Coto ALS, Kiraly VTR, Borges JC, De Maio A (2020a) Interaction of HSPA5 (Grp78, BIP) with negatively charged phospholipid membranes via oligomerization involving the N-terminal end domain. Cell Stress Chaperones

Dores-Silva PR, Cauvi DM, Kiraly VTR, Borges JC, De Maio A (2020b) Human HSPA9 (mtHsp70, mortalin) interacts with lipid bilayers containing cardiolipin, a major component of the inner mitochondrial membrane. Biochim Biophys Acta Biomembr 1862:183436

Ferrarini M, Heltai S, Zocchi MR, Rugarli C (1992) Unusual expression and localization of heat-shock proteins in human tumor cells. Int $\mathrm{J}$ Cancer 51:613-619

Fong-Ngern K, Sueksakit K, Thongboonkerd V (2016) Surface heat shock protein 90 serves as a potential receptor for calcium oxalate crystal on apical membrane of renal tubular epithelial cells. J Biol Inorg Chem 21:463-474

Gastpar R, Gehrmann M, Bausero MA, Asea A, Gross C, Schroeder JA, Multhoff G (2005) Heat shock protein 70 surface-positive tumor exosomes stimulate migratory and cytolytic activity of natural killer cells. Cancer Res 65:5238-5247

Gobbo J, Marcion G et al (2016) Restoring anticancer immune response by targeting tumor-derived exosomes with a HSP70 Peptide Aptamer. J Natl Cancer Inst 108(3). https://doi.org/10.1093/jnci/ djv330

Guidon PT Jr, Hightower LE (1986a) The 73 kilodalton heat shock cognate protein purified from rat brain contains nonesterified palmitic and stearic acids. J Cell Physiol 128:239-245

Guidon PT Jr, Hightower LE (1986b) Purification and initial characterization of the 71-kilodalton rat heat-shock protein and its cognate as fatty acid binding proteins. Biochemistry 25:3231-3239

Hartl FU, Hayer-Hartl M (2002) Molecular chaperones in the cytosol: from nascent chain to folded protein. Science 295:1852-1858

Hartl FU, Bracher A, Hayer-Hartl M (2011) Molecular chaperones in protein folding and proteostasis. Nature 475:324-332

Honda T, Horie M, Daito T, Ikuta K, Tomonaga K (2009) Molecular chaperone $\mathrm{BiP}$ interacts with Borna disease virus glycoprotein at the cell surface. J Virol 83:12622-12625

Horvath I, Multhoff G, Sonnleitner A, Vigh L (2008) Membraneassociated stress proteins: more than simply chaperones. Biochim Biophys Acta 1778:1653-1664
Ibrahim IM, Abdelmalek DH, Elshahat ME, Elfiky AA (2020) COVID19 spike-host cell receptor GRP78 binding site prediction. J Inf Secur 80:554-562

Kakimura J et al (2002) Microglial activation and amyloid-beta clearance induced by exogenous heat-shock proteins. FASEB J 16:601-603

Kiraly VTR, Dores-Silva PR, Serrao VHB, Cauvi DM, De Maio A, Borges JC (2020) Thermal aggregates of human mortalin and Hsp70-1A behave as supramolecular assemblies. Int J Biol Macromol 146:320-331

Kirkegaard T et al (2010) Hsp70 stabilizes lysosomes and reverts Niemann-Pick disease-associated lysosomal pathology. Nature 463:549-553

Klaips CL, Jayaraj GG, Hartl FU (2018) Pathways of cellular proteostasis in aging and disease. J Cell Biol 217:51-63

Kottom TJ, Hebrink DM, Limper AH (2018) Binding of Pneumocystis carinii to the lung epithelial cell receptor HSPA5 (GRP78). J Med Microbiol 67:1772-1777

Lamprecht C, Gehrmann M, Madl J, Romer W, Multhoff G, Ebner A (2018) Molecular AFM imaging of Hsp70-1A association with dipalmitoyl phosphatidylserine reveals membrane blebbing in the presence of cholesterol. Cell Stress Chaperones 23:673-683

Lauwers $\mathrm{E}$ et al (2018) Hsp90 mediates membrane deformation and exosome release. Mol Cell 71(689-702):e689

Lindquist S, Craig EA (1988) The heat-shock proteins. Annu Rev Genet 22:631-677

Lopez V, Cauvi DM, Arispe N, De Maio A (2016) Bacterial Hsp70 (DnaK) and mammalian Hsp70 interact differently with lipid membranes. Cell Stress Chaperones 21:609-616

Macazo FC, White RJ (2014) Monitoring charge flux to quantify unusual ligand-induced ion channel activity for use in biological nanoporebased sensors. Anal Chem 86:5519-5525

Mahalka AK, Kirkegaard T, Jukola LT, Jaattela M, Kinnunen PK (2014) Human heat shock protein 70 (Hsp70) as a peripheral membrane protein. Biochim Biophys Acta 1838:1344-1361

Mayer MP, Brehmer D, Gassler CS, Bukau B (2001) Hsp70 chaperone machines. Adv Protein Chem 59:1-44

Mills DR, Haskell MD, Callanan HM, Flanagan DL, Brilliant KE, Yang D, Hixson DC (2010) Monoclonal antibody to novel cell surface epitope on Hsc70 promotes morphogenesis of bile ducts in newborn rat liver. Cell Stress Chaperones 15:39-53

Minari K et al (2019) Thermodynamic analysis of interactions of the Hsp90 with adenosine nucleotides: a comparative perspective. Int J Biol Macromol 130:125-138

Mogk A, Bukau B, Kampinga HH (2018) Cellular handling of protein aggregates by disaggregation machines. Mol Cell 69:214-226

Morozova K et al (2016) Structural and biological interaction of hsc-70 protein with phosphatidylserine in endosomal microautophagy. J Biol Chem 291:18096-18106

Multhoff G, Hightower LE (2011) Distinguishing integral and receptorbound heat shock protein 70 (Hsp70) on the cell surface by Hsp70specific antibodies. Cell Stress Chaperones 16:251-255

Multhoff G et al (2020) Targeted natural killer cell-based adoptive immunotherapy for the treatment of patients with NSCLC after radiochemotherapy: a randomized phase II clinical trial. Clin Cancer Res 26:5368-5379

Nylandsted J et al (2004) Heat shock protein 70 promotes cell survival by inhibiting lysosomal membrane permeabilization. J Exp Med 200: 425-435

Pfaffenbach KT, Lee AS (2011) The critical role of GRP78 in physiologic and pathologic stress. Curr Opin Cell Biol 23:150-156

Pockley AG, Henderson B, Multhoff G (2014) Extracellular cell stress proteins as biomarkers of human disease. Biochem Soc Trans 42: 1744-1751

Rivera I, Capone R, Cauvi DM, Arispe N, De Maio A (2018) Modulation of Alzheimer's amyloid beta peptide oligomerization and toxicity by extracellular Hsp70. Cell Stress Chaperones 23:269-279 
Sahu R et al (2011) Microautophagy of cytosolic proteins by late endosomes. Dev Cell 20:131-139

Schilling D et al (2009) Binding of heat shock protein 70 to extracellular phosphatidylserine promotes killing of normoxic and hypoxic tumor cells. FASEB J 23:2467-2477

Shevtsov M, Balogi Z, Khachatryan W, Gao H, Vigh L, Multhoff G (2020) Membrane-associated heat shock proteins in oncology: from basic research to new theranostic targets Cells:9

Torok Z et al (2014) Plasma membranes as heat stress sensors: from lipidcontrolled molecular switches to therapeutic applications. Biochim Biophys Acta 1838:1594-1618

Tsutsumi S, Neckers L (2007) Extracellular heat shock protein 90: a role for a molecular chaperone in cell motility and cancer metastasis. Cancer Sci 98:1536-1539

Vega VL, De Maio A (2005) Increase in phagocytosis after geldanamycin treatment or heat shock: role of heat shock proteins. J Immunol 175: $5280-5287$

Vega VL et al (2008) Hsp70 translocates into the plasma membrane after stress and is released into the extracellular environment in a membrane-associated form that activates macrophages. J Immunol 180:4299-4307
Vega VL, Charles W, De Maio A (2010) A new feature of the stress response: increase in endocytosis mediated by Hsp70. Cell Stress Chaperones 15:517-527

Whitmore L, Wallace BA (2008) Protein secondary structure analyses from circular dichroism spectroscopy: methods and reference databases. Biopolymers 89:392-400

Wiener MC, White SH (1992) Structure of a fluid dioleoylphosphatidylcholine bilayer determined by joint refinement of x-ray and neutron diffraction data. III. Complete structure. Biophys J 61:434-447

Wimley WC, Hristova K, Ladokhin AS, Silvestro L, Axelsen PH, White SH (1998) Folding of beta-sheet membrane proteins: a hydrophobic hexapeptide model. J Mol Biol 277:1091-1110

Zhang $\mathrm{M}$ et al (2018) Interaction of Hsp90 with phospholipid model membranes. Biochim Biophys Acta Biomembr 1860:611-616

Publisher's note Springer Nature remains neutral with regard to jurisdictional claims in published maps and institutional affiliations. 